\title{
Identifikasi Pola Morfologi Perkampungan Adat Nagari Koto Hilalang Sumatera Barat Berdasarkan Kearifan Lokal
}

\section{Identification of Morphological Patterns of Indigenous Villages of Nagari Koto Hilalang, West Sumatra Based on Local Wisdom}

\author{
Siti Aisyah Adelina Putri ${ }^{\mathrm{a}}$, Nurini ${ }^{\mathrm{b}}$ * \\ ${ }^{a}$ Departemen Perencanaan Wilayah dan Kota Universitas Diponegoro, Semarang, Indonesia \\ ${ }^{a}$ Departemen Perencanaan Wilayah dan Kota Universitas Diponegoro, Semarang, Indonesia
}

\begin{abstract}
Abstrak
Kampung Adat Nagari Koto Hilalang merupakan nagari yang berada di Kecamatan Kubung, Kabupaten Solok yang ditetapkan sebagai perkampungan adat oleh Dinas Pariwisata Kabupaten Solok. Penetapan tersebut didasarkan masih dipertahankannya kearifan lokal yang ada di nagari tersebut. Kearifan lokal tentunya mempengaruhi aktivitas masyarakat yang berkaitan erat dengan pola morfologi wilayahnya. Adanya kearifan lokal tersebut tentu membentuk suatu pola morfologi yang unik dan berbeda dengan wilayah lain di Indonesia. Untuk itu perlu dilakukan penelitian lebih lanjut untuk melihat bagaimana pola morfologi yang dipengaruhi oleh kearifan lokal tersebut. Berdasarkan perumusan masalah tersebut maka pertanyaan penelitian yang muncul yaitu Bagaimana pola morfologi Kampung Adat Nagari Koto Hilalang Sumatera Barat yang berdasarkan kearifan lokal (?). Untuk menjawab pertanyaan penelitian tersebut, penelitian ini menggunakan metode analisis kuantitatif dengan teknik analisis deskriptif kuantitatif dan analisis deskriptif kualitatif. Berdasarkan analisis yang dilakukan didapatkan pola morfologi perkampungan adat Nagari Koto Hilalang terlihat pada kearifan lokal masyarakatnya dalam mengatur segala tata kehidupan di perkampungan adat Nagari Koto Hilalang yaitu aturan dalam pembagian wilayah yang didasarkan kepada adat istiadat orang Minangkabau sehingga terbentuk taratak, dusun, koto dan nagari. Aturan masyarakatnya yang demikian menyebabkan morfologi kawasannya tergolong kepada bentuk Organic Pattern dimana Nagari Koto Hilalang terbentuk secara alami/spontan, berkembang sesuai kebutuhan masyarakat yang terikat kepada aturan adat yang turun temurun dari nenek moyang orang Minangkabau. Dalam penelitian ini juga diberikan rekomendasi ataupun arahan bagi pemuka adat, pemerintah, dan masyarakat dalam mempertahankan morfologi perkampungan adat Nagari Koto Hilalang.
\end{abstract}

Kata kunci: Morfologi, Kearifan Lokal, Kampung Adat

\begin{abstract}
Nagari Koto Hilalang is one of the indigenous villages that located in Gunung Talang district, Solok Regency. This village has been known as one of tourism center in Solok regency referred to the citizen's activity. The existency of the local wisdom affects the society's activity due to the pattern of the area's morphology. The presence of the local wisdom certainly form a morphological pattern and make it unique and different from the other regions. This research questioned the morphology of Nagari Koto Hilalang based on the local wisdom's morphology. To answer the question of the research, this scientist used the qualitative and quantitative techniques. The analysis result obtained that the morphology pattern of Nagari Koto Hilalang is arranged based on the local wisdom of Minangkabau's culture, such as taratak, dusun, koto, dan nagari. The rules of society that cause its morphology region belongs to form Organic Pattern where Nagari Koto Hilalang formed naturally/spontaneously because of the growing needs of society that is bound to the custom rule which has been hereditary from ancestors of the minangkabau people. In this study also provided recommendations of referrals for indigenous leaders, government, and community in sustaining indigenous villages (Nagari) morphology of Koto Hilalang.
\end{abstract}

Keyword: Morphology, Local Wisdom, Indigenous Villages

\footnotetext{
* Corresponding author. Siti Aisyah Adelina Putri.

E-mail address: tisyaputri17@gmail.com.
} 


\section{Pendahuluan}

Kota memiliki pemahaman yang terdiri dari 2 aspek yang tidak dapat dipisahkan. Aspek pertama yaitu aspek fisik yang berasal dari alam yang mewakili wujud ruang beserta elemenelemennya. Aspek yang kedua yaitu manusia yang berperan sebagai subjek pembangunan dan yang pengguna ruang kota (Soetomo, 2009). Kota selalu mengalami perkembangan dari waktu ke waktu. Perkembangan kota dipengaruhi oleh perubahan fisik, ekonomi, sosial, budaya, politik, dan teknologi (Yunus, 1999). Morfologi perkotaan adalah penataan atau formasi keadaan kota yang sebagai objek dan sistem yang dapat diselidiki secara struktural, fungsional, dan visual. Tinjauan terhadap morfologi kota ditekankan pada bentuk-bentuk fisikal dari lingkungan kekotaan dan hal ini dapat diamati dari kenampakan kota secara fisikal antara lain tercermin pada sistem jalan-jalan yang ada, blok-blok bangunan baik daerah hunian ataupun bukan (perdagangan/industri) dan juga bangunan-bangunan individual. Morfologi berasal dari kata morf yang berarti bentuk, sehingga morfologi dapat diartikan sebagai bentuk kenampakan fisik kawasan (James \& Bound, 2009). Morfologi perkotaan adalah penataan atau formasi keadaan kota yang sebagai objek dan sistem yang dapat diselidiki secara struktural, fungsional, dan visual (Zahnd, 1999). Menurut (Zahnd, 1999) pola morfologi tersebut tidak terjadi secara abstrak, yang artinya perkembangan kota berlangsung dalam 4 dimensi yaitu kondisi ruang yang berkaitan dengan produk, waktu yang berkaitan dengan proses perkembangan, perilaku manusia dalam memanfaatkan ruang serta aktivitas yag ada dalam ruang.

Indonesia merupakan negara yang memiliki beragam budaya yang menghasilkan nilainilai lokal serta tata cara kehidupan yang unik dan arif. Nilai-nilai lokal ini menjadi pengetahuan praktis dalam rangka bertahan hidup dan membentuk alam lingkungannya. Nilainilai lokal tersebut dapat terlihat pada kampung-kampung yang ada di Indonesia. Kampung merupakan salah satu bagian dari daerah di Indonesia yang mencerminkan kekhasan suatu daerah. Kampung menurut kamus Bahasa Indonesia adalah desa, dusun, atau kelompok rumahrumah yang merupakan bagian kota dan biasanya rumah-rumahnya kurang bagus. Sementara itu, Kampuang menurut pengertian orang Minangkabau terdahulu disebut sebagai suatu wilayah/kawasan yang didiami oleh orang yang sesuku atau sukunya sejenis saja atau tidak bercampur dengan suku lain. Kampung Adat Nagari Koto Hilalang merupakan salah satu nagari yang berada di Kecamatan Kubung, Kabupaten Solok yang ditetapkan sebagai perkampungan adat oleh Dinas Pariwisata Kabupaten Solok. Nagari Koto Hilalang dikelilingi oleh perbukitan, hutan, sawah dan ladang sehingga menampilkan bentuk landscape yang unik. Selain bentuk landscape yang unik, Nagari Koto Hilalang juga masih mempertahankan kearifan lokal yang dimiliki hingga kini.

Umumnya kawasan yang masih memiliki keaslian daerah seperti ini memiliki morfologi daerah yang berbeda. Pola morfologi daerah yang unik tersebut dapat dilihat dengan meninjau product, process, dan behaviour yang terjadi di perkampungan tersebut. Selain itu dengan adanya kearifan lokal budaya Minangkabau yang masih dipertahankan hingga saat ini membentuk morfologi daerah yang berbeda dengan morfologi daerah yang ada di Pulau Jawa dan daerah lainnya di Indonesia yang sudah banyak diteliti. Oleh karena itu perlu dilakukan penelitian melihat bagaimana pola morfologi dari perkampungan adat Nagari Koto Hilalang tersebut karena belum pernah diteliti sebelumnya.

\section{2. $\quad$ Metode}

Metode yang akan digunakan pada penelitian "Identifikasi Pola Morfologi Perkampungan Tradisi Nagari Koto Hilalang Sumatera Barat dan Kearifan Lokal yang Membentuknya" adalah metode deskriptif kuantitatif. Pendekatan kuantitatif pada penelitian ini akan digunakan untuk menjelaskan variabel yang akan digunakan dalam penelitian yang berangkat dari teori dengan kata lain dapat dikatakan penelitian ini menjelaskan gambaran atau kondisi real di lapangan dengan melihat teori yang ada serta didukung dengan dokumen-dokumen perencanaan yang terkait. Penelitian ini juga akan didukung dengan wawancara sebagai pelengkap kepada narasumber untuk memperoleh informasi yang valid. Teknik analisis yang digunakan yaitu deskriptif kualitatif dan deskriptif kuantitatif. Selanjutnya data yang didapat dari kedua analisis tersebut digabungkan dan dibandingkan sehingga dapat ditemukan data kualitatif yang memperkuat dan memperluas data kuantitatif. Teknik analisis kualitatif digunakan pada analisis 
mengenai sejarah Perkampungan Adat Nagari Koto Hilalang, aktivitas sosial budaya masyarakat dan kondisi fisik serta kondisi non fisik perkampungan Adat Nagari Koto Hilalang. Analisis Deskriptif Kuantitatif digunakan untuk mentransformasikan data angka dari kuesioner kepada masyarakat dan tokoh masyarakat yang kemudian dideskripsikan agar mudah dimengerti.

\section{Kajian Morfologi Kampung Adat Berdasarkan Kearifan Lokal}

Morfologi bukan merupakan kajian yang statis yang hanya mempelajari bentuk fisik meliputi ketinggian bangunan, susunan jaringan jalan, serta komposisi dan proporsi bangunan dalam suatu bentang kota (townscape), melainkan berusaha menggali proses yang melatarbelakangi perubahan serta dinamika terbentuknya lingkungan perkotaan dengan lingkungan fisik sebagai representasinya. Morfologi memiliki tiga komponen dalam mencermati kondisi fisik kawasan. Komponen tersebut ditinjau dari penggunaan lahan kawasan yang mencerminkan aktivitas kawasan, pola sirkulasi atau pola jaringan jalan yang menghubungkan antar kawasan, dan pola bangunan beserta fungsinya (Soetomo, 2009). Ada tiga sistem pola jaringan jalan yaitu pola jalan tidak teratur (Irregular Sysytem), pola jalan radial konsentris (Radial Concentric System) dan pola jalan bersiku (Grid).

Menurut (Kostof, 1991), kota adalah leburan dari bangunan dan penduduk, sedangkan bentuk kota pada awalnya adalah netral tetapi kemudian berubah sampai hal ini dipengaruhi dengan budaya yang tertentu. Bentuk kota ada dua macam yaitu Planned dan Unplanned. Bentuk Planned (terencana) dapat dijumpai pada kota-kota eropa abad pertengahan dengan pengaturan kota yang selalu regular dan rancangan bentuk geometrik. Bentuk Unplanned (tidak terencana) banyak terjadi pada kota-kota metropolitan, dimana satu segmen kota berkembang secara sepontan dengan bermacam-macam kepentingan yang saling mengisi sehingga akhirnya kota akan memiliki bentuk semaunya yang kemudian disebut dengan organik pattern. Bentuk unplanned ini banyak ditemui di daerah pedesaan maupun perkampungan yang tumbuh secara alami tanpa ada perencanaan.

Teori place fokus kepada pemahaman kota yang terdiri atas konteks kota, citra kota. Menurut Lynch,1960 (Dalam Weishaguna, 2007) teori place fokus kepada pemahaman kota yang terdiri atas konteks kota, citra kota yang memiliki lima elemen meliputi (path, edges, district, nodes, dan landmark) : 1. Path (jalur), Merupakan jalur atau rute sirkulasi yang sangat penting untuk melakukan pergerakan. Secara fisik paths merupakan salah satu unsur pembentuk kota. 2. Edge (Tepian), Merupakan batasan antar kawasan yang berfungsi sebagai pemutus atau pemisah. Edge dapat berupa suatu desain, jalan, sungai, gunung. Edge memiliki identitas yang kuat karena tampak visualnya yang jelas. 3. Distrik (Kawasan), Merupakan kawasan perkotaan dengan karakteristik aktivitas tertentu. Sebuah kawasan district memiliki ciri khas yang mirip (bentuk, pola dan wujudnya) dan khas pula dalam batasnya yang dapat dilihat sebagai referensi interior maupun eksterior. 4. Nodes (Simpul), Merupakan tempat dimana terdapat ruas-ruas jalan yang mengakibatkan arus saling bertemu misalnya persimpangan lalu lintas, stasiun, lapangan terbang, jembatan dan lain-lain. Node juga merupakan suatu tempat orang mempunyai perasaan 'masuk' dan 'keluar' dalam tempat yang sama. 5. Landmark (Tengeran), Merupakan elemen yang berupa monumen, gedung, menara, dan lainnya yang dapat menjadi ciri untuk mengenali suatu daerah.

Kampung adalah permukiman manusia atau masyarakat berkelompok, lebih besar dari dusun tetapi lebih kecil dari kota yang memiliki populasi mulai dari kepadatan rendah sampai kepadatan penduduk yang tinggi (Astuti, 2014). Kampung biasanya terbentuk pada lahan-lahan kosong dan terbuka disepanjang aliran sungai maupun tepian rel kereta api dan lambat laun berkembang dengan kepadatan penduduk sebesar 300-400 jiwa/ha (Wahjoerini, 2014). Kampung biasanya memiliki sifat-sifat kawasan yang tumbuh secara organik, antara lain mempunyai hubungan sosial masyarakat yang sangat erat, rasa kebersamaan yang tinggi, terjalinnya hubungan yang harmonis antara manusia dan alam, dan terjadinya kelestarian lingkungan. Kampung Adat merupakan suatu komunitas tradisional yang masih kuat mempertahankan adat dan berada dalam satu kesatuan wilayah dimana masyarakat yang tinggal disana secara bergotong-royong. Kampung adat memiliki daya tarik tersendiri karena kekhasannya, daya tarik tersebut meliputi daya tarik untuk dijadikan objek wisata maupun untuk dijadikan objek penelitian (Kusumawati, 2015). 
Pada sebuah buku Arsitektur Tradisional Daerah Sumatera Barat, 1999 (dalam Nelisa, 2014) dijelaskan bahwa perkampungan penduduk Minangkabau disebut dengan Nagari. Nagari terdiri dari 3 bagian utama yang menjadi dasar berdirinya nagari tersebut. yaitu Taratak, dusun dan koto. Taratak merupakan sebuah perkampungan kecil yang terbentuk ketika masyarakat mulai mencari lahan baru untuk sawah dan ladang. Dusun merupakan gabungan dari beberapa buah Taratak yang telah berkembang, sedangkan koto merupakan gabungan dari beberapa dusun atau dusun yang telah berkembang dan memenuhi persyaratan untuk menjadi koto.

Menurut Atmojo, 1986 (dalam Qodariah, 2013) kearifan lokal merupakan kemampuan penyerapan kebudayaan asing yang secara selektif, artinya disesuaikan dengan suasana dan kondisi setempat. Dalam arti lain kearifan lokal merupakan sesuatu yang terbentuk sebagai keunggulan budaya yang dimiliki oleh masyarakat setempat yang merupakan suatu produk budaya masa lalu yang terjadi secara terus menerus dan dijadikan sebagai pedoman hidup (Fatma, 2014). Bentuk-bentuk kearifan lokal yang ada di masyarakat menurut Sartini, 2006 (dalam Basyari, 2014) dapat berupa nilai, norma, kepercayaan, dan aturan-aturan khusus.

Orientasi dalam pembangunan rumah di Minangkabau biasanya memperhatikan keamanan, kepercayaan dan kesehatan. Menurut orang zaman dahulu arah rumah tidak boleh membelakangi Gunung Marapi, namun pendapat tersebut lama kelamaan mulai hilang semenjak adanya jalan raya yang menghubungkan antara satu Nagari ke Nagari lain sehingga orientasi rumah mulai menghadap ke jalan raya (Dewi, 2010). Bangunan dan kawasan suatu kota merupakan hal-hal penting di dalam sejarah pembangunan suatu kota. Bangunan-bangunan lama ataupun kebudayaan asli dari suatu daerah patut dijaga kelestariannya sebab mengandung unsur-unsur sejarah pada waktu tertentu yang tidak akan terjadi lagi (Nelisa, 2014). Menurut Attoe (dalam Heryanto, 2011) seni bangunan, monumen, taman, dan suasana kota mempunyai latar belakang sejarah, dan memiliki nuansa yang khusus sehingga harus dilestarikan agar dapat menjadi ciri atau jati diri pada lanskap kota. Bentuk kota yang didasarkan kepada kaidah sosial budaya akan terbentuk dan berkembang sesuai dengan penggunaannya serta mengikuti peradaban yang dianut oleh masyarakatnya dari waktu ke waktu (Heryanto, 2011).

\section{Analisis Pola Morfologi Perkampungan Adat Nagari Koto Hilalang Sumatera Barat Berdasarkan Kearifan Lokal}

Analisis yang dilakukan pada penelitian ini adalah analisis pola morfologi perkampungan adat Nagari Koto Hilalang berdasarkan kearifan lokal yang didapatkan dengan menggabungkan analisis yang dilakukan meliputi analisis kondisi fisik perkampungan, analisis kondisi fisik binaan perkampungan, dan analisis kearifan lokal. Analisis kondisi fisik alam dilakukan untuk mengetahui bagaimana bentangan alam yang membentuk Nagari Koto Hilalang sehingga terbentuk sebuah landsekap yang unik. Analisis kondisi fisik binaan dilakukan untuk melihat bagaimana pola perkampungan, pola jalan dan bentuk arsitektur yang ada di Kampung Adat Nagari Koto Hilalang. Sementara itu, analisis kearifan lokal Nagari Koto Hilalang dilakukan untuk mengidentifikasi bagaimana kearifan lokal dapat mempengaruhi bentuk morfologi dari perkampungan adat Nagari Koto Hilalang tersebut.

Berdasarkan survey yang dilakukan masyarakat di Nagari Koto Hilalang sebanyak 92\% masyarakatnya berpendapat bahwa masih memiliki kesadaran untuk selalu mempertahankan tradisi-tradisi adat yang dimilikinya. Adapun tradisi-tradisi yang terdapat di Nagari Koto Hilalng yaitu Turun Mandi, Akikah, Sunat Rosul, Khatam Qur'an, Perkawinan, Upacara Kematian, dan Batagak Gala. Semua tradisi adat tersebut dilakukan di dalam nagari itu sendiri, karena tanpa adanya wadah berupa ruang-ruang fisik yang tersedia, maka semua tradisi adat tersebut tidak dapat dilakukan. Ruang-ruang fisik tersebut tentu saja berada di dusun ataupun di koto. Pada kawasan dusun sudah terdapat ruang-ruang fisik berupa Rumah Gadang, Rumah Satungkuik Nasi, Surau dan tempat pemandian. Sementara itu, pada kawasan koto sudah lebih lengkap dibandingkan dusun yaitu sudah terdapat fasilitas seperti lapangan, masjid, dan balai adat yang dapat digunakan untuk melakukan tradisi-tradisi adat oleh masyarakat seperti yang tertera pada gambar dibawah ini: 


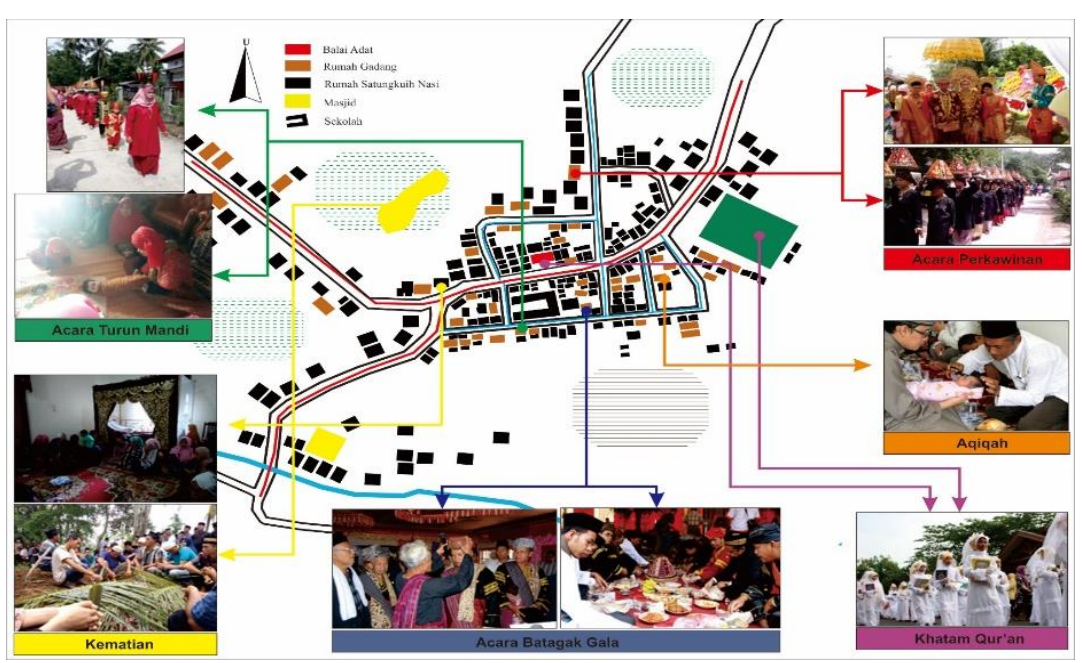

Gambar 1. Ruang-Ruang Fisik Yang Mewadahi Aktivitas Adat Istiadat di Nagari Koto Hilalang (Analisis Penulis, 2018)

Pada analisis kondisi fisik alam, Nagari Koto Hilalang sangat dipengaruhi oleh kondisi topografi yang berbukit dan berlembah. Hal tersebut disebabkan karena Nagari Koto Hilalang berada di ketinggian 600-700 meter dari permukaan laut sehingga memiliki suhu rata-rata 25$31{ }^{\circ} \mathrm{C}$ dengan curah hujan $192 \mathrm{~mm}$. Kondisi alam yang unik ini berdampak terhadap pembentukan nagari itu sendiri. Daerah yang memiliki topografi rendah digunakan sebagai lahan permukiman dan persawahan, sedangkan lahan yang terdiri dari perbukitan dan lembah digunakan sebagai lahan perkebunan atau perladangan. Lahan yang merupakan permukiman dan persawahan tersebut pada zaman dahulu disebut sebagai dusun, sedangkan daerah perbukitan yang terdapat perladangan disebut dengan taratak, biasanya di taratak tersebut hanya terdapat berupa lahan perladangan. Keberadaan taratak yang tersebar di daerah tersebut membentuk jalan dengan pola yang tidak teratur akibat keberadaan pembangunan permukiman tidak teratur yang membentuk sebuah kelompok-kelompok mengikuti kondisi topografi Nagari Koto Hilalang. Oleh sebab itu, kawasan yang memiliki topografi rendah menjadi dusun dan koto dimana banyak terdapat permukiman penduduk. Berikut dijelaskan perbedaan antara taratak, dusun, dan koto:

Tabel 1. Perbedaan Antara Taratak Dusun Dan Koto (Hasil Analisis Penulis, 2018)

\begin{tabular}{|c|c|c|c|}
\hline Ciri-Ciri & Taratak & Dusun & Koto \\
\hline & $\begin{array}{l}\text { Bagian terkecil dari } \\
\text { permukiman di } \\
\text { Minangkabau }\end{array}$ & $\begin{array}{l}\text { Beberapa taratak yang } \\
\text { telah berkembang }\end{array}$ & $\begin{array}{l}\text { Gabungan dari beberapa dusun } \\
\text { yang telah berkembang }\end{array}$ \\
\hline $\begin{array}{l}\text { Kondisi } \\
\text { Permukiman }\end{array}$ & $\begin{array}{l}\text { Terdiri dari rumah- } \\
\text { rumah kecil yang } \\
\text { disebut Dangau }\end{array}$ & $\begin{array}{l}\text { - Sudah mulai dibangun } \\
\text { rumah-rumah } \\
\text { permanen. } \\
\text { - Sudah boleh dibangun } \\
\text { rumah gadang yang } \\
\text { memiliki } 2 \text { gonjong }\end{array}$ & $\begin{array}{l}\text { - Jumlah rumah permanen } \\
\text { semakin banyak, } \\
\text { - Sudah boleh dibangun rumah } \\
\text { gadang dengan } 4 \text { gonjong. }\end{array}$ \\
\hline $\begin{array}{l}\text { Yang } \\
\text { mendiami }\end{array}$ & Keluarga saparuik & $\begin{array}{l}\text { Gabungan dari keluarga } \\
\text { saparuik yang sudah } \\
\text { terdiri dari berbagai suku }\end{array}$ & $\begin{array}{l}\text { Terdiri dari beberapa kaum yang } \\
\text { masing-masing kaum senenek }\end{array}$ \\
\hline Pemimpin & Tuo Taratak & Tuo Dusun & Datuak \\
\hline $\begin{array}{l}\text { Kondisi } \\
\text { Kawasan }\end{array}$ & $\begin{array}{l}\text { Didominasi oleh } \\
\text { lahan pertanian }\end{array}$ & $\begin{array}{l}\text { Sudah mulai banyak } \\
\text { rumah-rumah namun } \\
\text { masih didominasi oleh } \\
\text { lahan pertanian }\end{array}$ & $\begin{array}{l}\text { Permukiman semakin padat tetapi } \\
\text { masih terdapat lahan pertanian }\end{array}$ \\
\hline Fasilitas & $\begin{array}{l}\text { Belum } \\
\text { fasilitas }\end{array}$ & Surau (Musholla) & $\begin{array}{l}\text { Balai adat, masjid, tepian (tempat } \\
\text { mandi dan mengambil air), } \\
\text { pandam pakuburan (kuburan), } \\
\text { lapangan }\end{array}$ \\
\hline $\begin{array}{l}\text { Kondisi } \\
\text { Jalan }\end{array}$ & Masih jalan setapak & $\begin{array}{l}\text { Sudah } \\
\text { perkerasan }\end{array}$ & Sudah beraspal \\
\hline
\end{tabular}




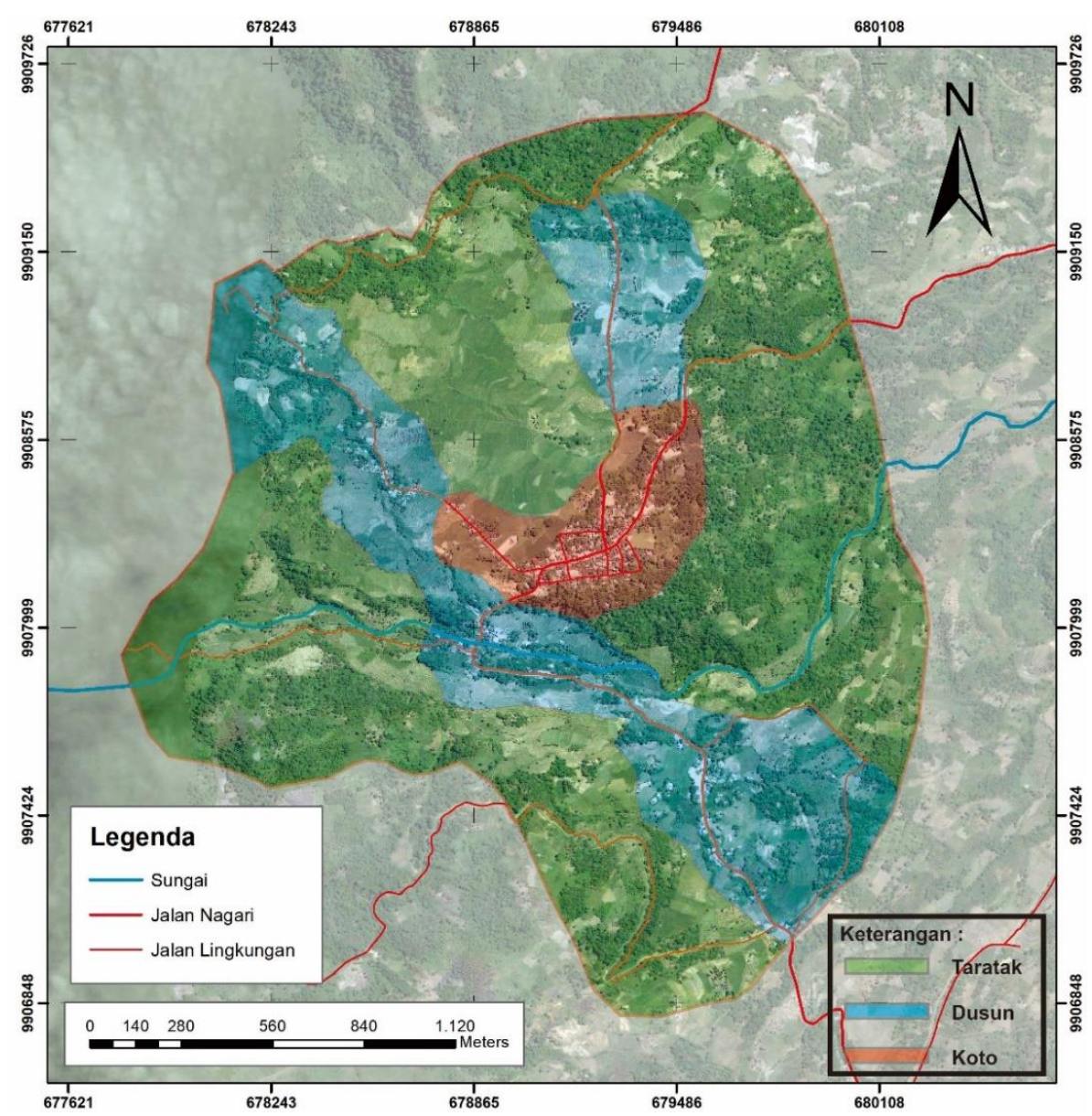

Gambar 2. Peta Pembagian Kawasan Menurut Nenek Moyang Minangkabau (Analisis Penulis, 2018)

Pada analisis kondisi fisik binaan, pola perkampungan terdiri atas beberapa tingkatan mulai dari yang terendah hingga yang tertinggi yaitu taratak, dusun, dan koto. Pembagian kawasan tersebut telah ditetapkan oleh nenek moyang Minangkabau sejak zaman dahulu. Taratak merupakan tingkatan wilayah terkecil yang terdiri dari perkebunan dan bangunan berupa rumah-rumah kecil yang bersifat sementara yang digunakan untuk tempat beristirahat ketika bertani dan ada pula yang permanen yang digunakan sebagai tempat tinggal. Dusun setingkat lebih luas dari taratak yang sudah terdapat bangunan rumah dan jalan setapak sebagai akses bagi masyarakat. Sementara itu, koto sudah memiliki fasilitas yang cukup lengkap berupa masjid, jalan umum, balai adat, MCK dan sebagainya. Seiring perkembangan zaman muncullah istilah Nagari yang ditetapkan oleh pemerintahan daerah sehingga Koto Hilalang berubah menjadi Nagari Koto Hilalang. Suatu perkampungan dapat disebut sebagai nagari selain harus memiliki balai adat, masjid, dan jalan sebagai sarana transportasi, lapangan, serta tempat pemandian, hal terpenting yang harus dimiliki adalah memiliki sistem pemerintahan yang sempurna. Nagari sendiri merupakan kumpulan sekurang-kurangnya 4 koto atau disebut dengan ampek suku (empat suku). Berikut terdapat unsur-unsur yang harus dimiliki oleh sebuah nagari:

1. Balabuah (menghubungkan kampung dengan kampung).

2. Batapian tampek mandi (tempat mandi umum) yang biasanya berada ditepi sungai. Jika tidak terdapat sungai biasanya berasal dari sumur umum atau air dari bukit yang ditampung disuatu waduk kecil yang disebut Luak.

3. Babalai Adat (tempat pendidikan adat, musyawarah nagari, kaum ataupun suku dan tempat menegakkan hokum adat).

4. Bamusajik (tempat beribadah terutama (Sholat Jum'at yang harus dilaksanakan di masjid nagari), tempat Pendidikan agama, MDA dan sebagainya).

5. Bagalanggang (tempat bermain bagi anak-anak muda, tempat mengadakan pertunjukan dalam rangka peringatan yang dilakukan nagari).

Berikut lokasi unsur-unsur yang harus dimiliki oleh sebuah nagari yang akan dijelaskan pada gambar dibawah ini: 


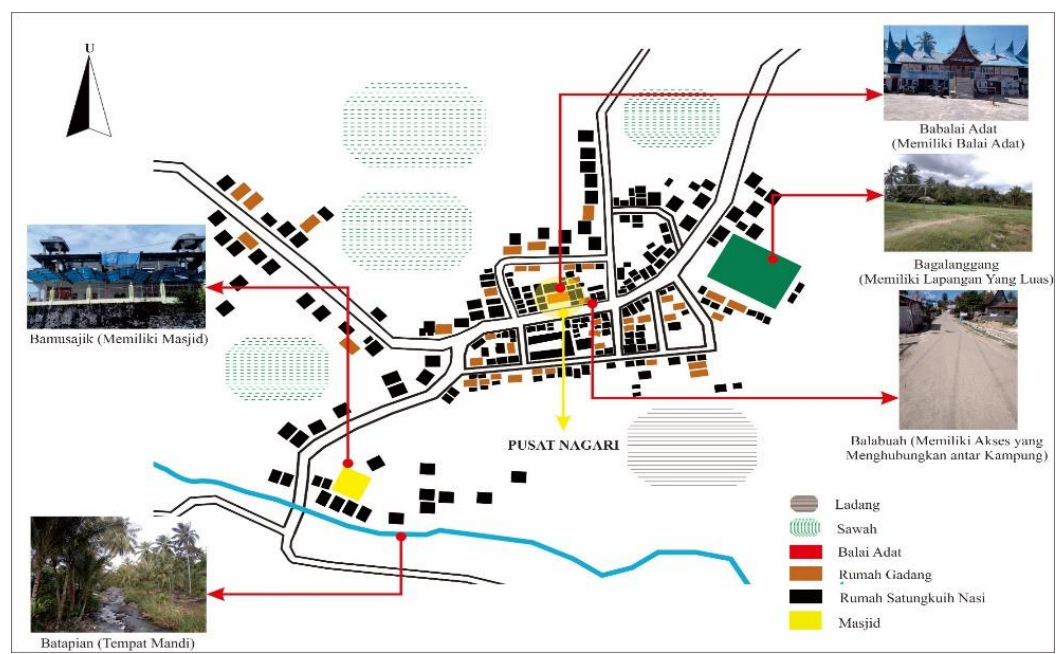

Gambar 3. Unsur-Unsur Nagari (Analisis Penulis, 2018)

Pola jaringan jalan pada Nagari Koto Hilalang terbentuk secara natural/tidak teratur (irregular grid) karena terbentuk dari kawasan perkampungan yang terbentuk secara natural pula. Jalan yang terdapat di Nagari Koto Hilalang mengikuti letak-letak bangunan dan penggunaan lahan yang sudah ada, terlihat dari jalan utama penghubung antar nagari yang mengikuti bangunan yang sudah dibangun. Selain itu pola jalan di Nagari Koto Hilalang juga dipengaruhi oleh topografi nagari yang berbukit dan berlembah. Adanya topografi yang demikian membuat bentuk dan ukuran jalan di Nagari Koto Hilalang bervariasi. Untuk jalan yang menghubungkan Nagari Koto Hilalang dengan nagari lain (jalan utama) sudah memiliki kondisi yang baik dengan menggunakan aspal dengan lebar \pm 3 meter. Sementara itu, jalan antar jorong nagari (jalan lingkungan) jalan lingkungan yang ada di Nagari Koto Hilalang hanya bisa dilalui oleh satu mobil dan dibuat dengan menggunakan semen serta masih ada jalan yang hanya sekedar tanah saja dengan lebar \pm 2 meter. Dengan bertambahnya jumlah penduduk maka bertambah pula banguan-bangunan rumah baru yang dibangun oleh masyarakat sekitar, oleh sebab itu muncullah jalan baru atau jalan setapak dengan lebar \pm 1 meter yang kondisinya belum cukup baik dan hanya dapat dilalui oleh sepeda motor saja. Berikut dilampirkan penjelasan jaringan jalan yang ada di Nagari Koto Hilalang:

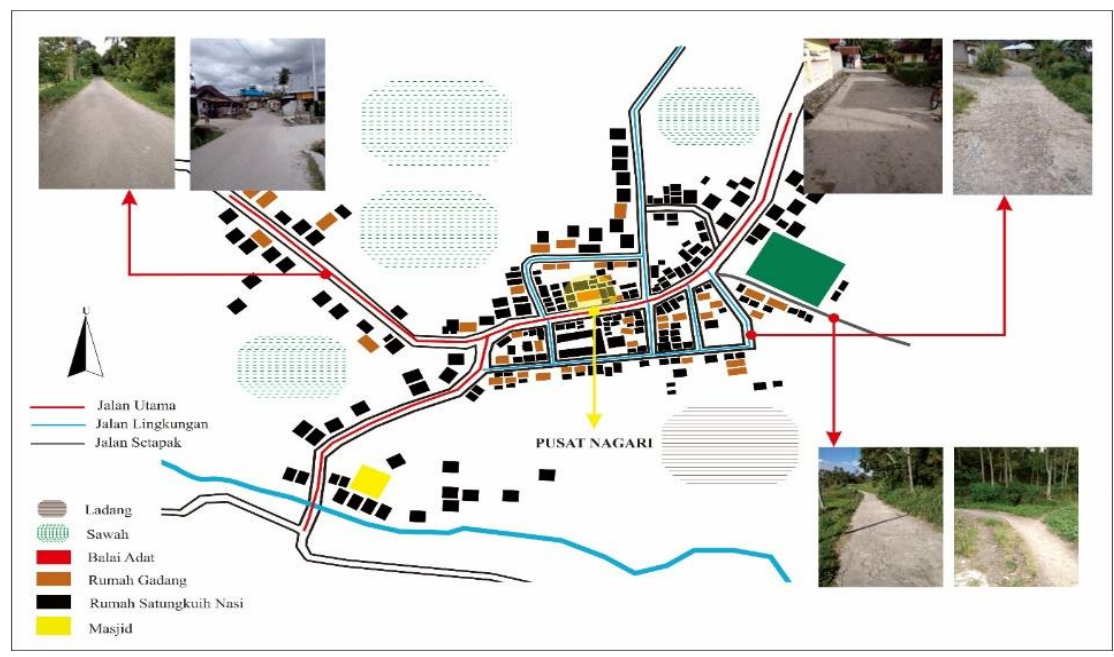

Gambar 4. Kondisi Beberapa Jaringan Jalan di Nagari Koto Hilalang (Analisis Penulis, 2018)

Masyarakat Minangkabau sangat menjunjung tinggi adat dan kebudayaan yang diturunkan oleh nenek moyangnya. Adat istiadat menjadi sumber pengetahuan bagi masyarakat nya dalam melakukan kegiatan apa saja, termasuk dalam penggunaan lahan dan menata perkampungan mereka, seperti pepatah berikut yang mengatakan :

Nan data kaparumah (Tanah yang datar untuk perumahan)

Nan lereng tanami tebu (Tanah yang lereng untuk ditanami tebu) 
Nan payua karanang itiak (Tanah yang rawa untuk itik berenang)

Nan barayia jadikan sawah (Tanah berair untuk persawahan)

Nan munggu kapakuburan (Tanah yang tinggi untuk kuburan)

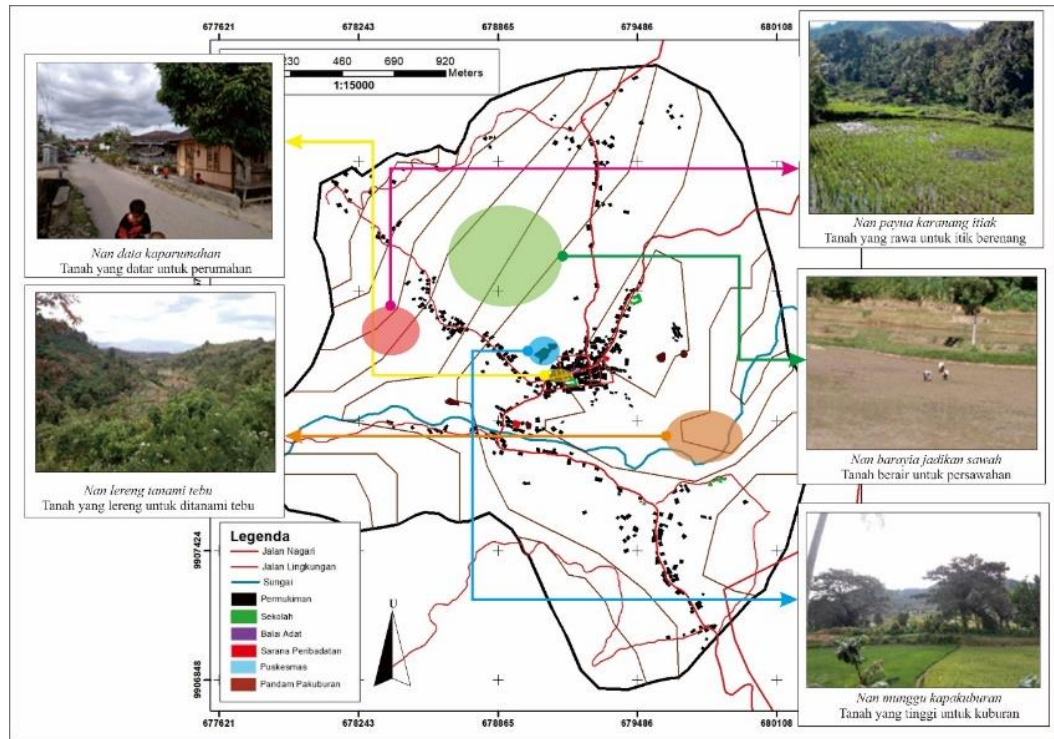

Gambar 5. Cara Penggunaan Lahan Menurut Orang Minangkabau (Analisis Penulis, 2018)

Analisis place dilakukan untuk memudahkan dalam mengenali setiap tempat atau ruang kota dengan melihat pada ciri yang dimiliki dan diwujudkan dalam bentuk citra kota dan aktivitas masyarakatnya. Analisis place merupakan analisis yang digunakan sebagai makna dari sebuah kawasan, khususnya kawasan Nagari Koto Hilalang, Sumatera Barat yang merupakan salah satu kawasan yang memiliki budaya daerah yang kental dan masih dipertahankan hingga kini. Adanya lima elemen penting dalam teori place sangat berpengaruh bagi Nagari Koto Hilalang, dengan adanya ciri khas dan keaslian budaya yang masih dipertahankan hingga kini menjadi karakteristik tersendiri bagi orang-orang untuk mengenali Nagari Koto Hilalang sebagai kampung adat. Analisis place memiliki lima elemen yang membentuknya yaitu path (jalur), edges (tepian), district (kawasan), nodes (simpul), dan landmark (symbol kawasan). Dari kelima elemen tersebut terbentuklah suatu ciri khas pada Nagari Koto Hilalang yang memiliki pola perkampungan asli sesuai dengan adat Minangkabau yang dijabarkan pada gambar dibawah ini:

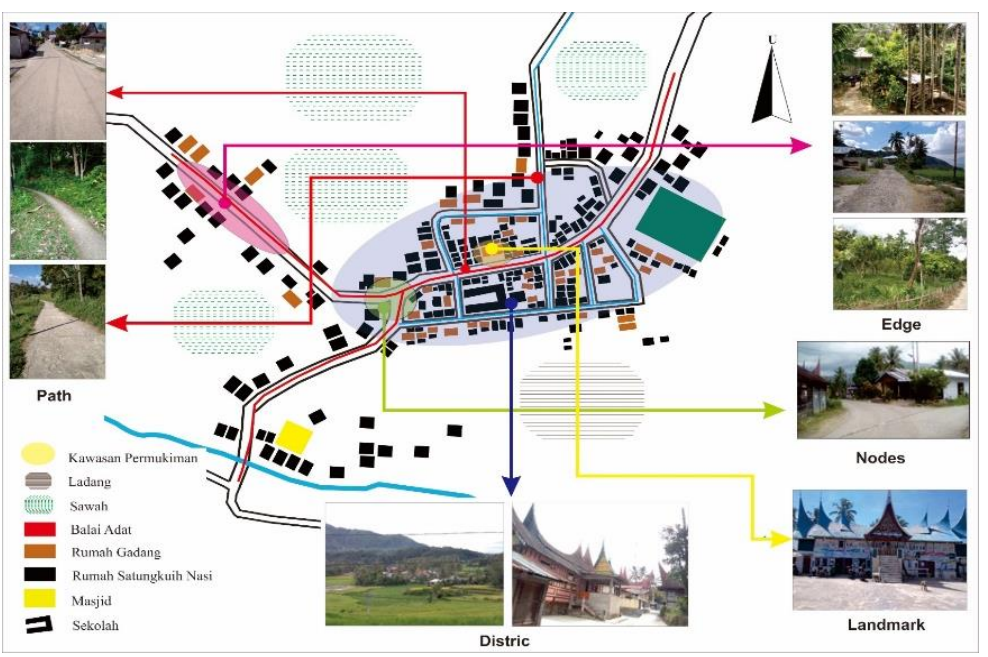

Gambar 6. Analisis Place Nagari Koto Hilalang (Analisis Penulis, 2018)

Berdasarkan analisis-analisis yang dilakukan didapatkan pola morfologi perkampungan adat Nagari Koto Hilalang yang diuraikan sebagai berikut yaitu berdasarkan kondisi fisik alam di Nagari Koto Hilalang yang berbukit dan berlembah membuat perkembangan nagari tidak 
merata di seluruh wilayahnya. Oleh sebab itu, pembangunannya hanya terkonsentrasi di beberapa tempat saja yang memiliki topografi yang cukup aman untuk ditinggali. Hal tersebut menjadikan Nagari Koto Hilalang digolongkan kepada bentuk Organic Pattern yang terbentuk secara natural/spontan (hanya mengikuti aturan yang telah ditetapkan adat yang telah disepakati oleh orang-orang terdahulu), alasan lainnya yaitu karena nagari Koto Hilalang berkembang sesuai dengan kebutuhan masyarakatnya serta dipengaruhi oleh kondisi topografi nagari yang berbukit dan berlembah. Sementara itu, untuk pola perkampungan, Nagari Koto Hilalang memiliki pola permukiman memusat, dimana pusatnya berada di kawasan Koto tepatnya di Jorong Dalam Nagari yang permukimannya mayoritas berada disana dan memiliki fasilitasfasilitas berupa Balai Adat, Masjid, Sekolah, Lapangan yang dijadikan sebagai pusat aktivitas masyarakatnya.

\section{Kesimpulan dan Rekomendasi}

Kesimpulan yang dapat diambil berdasarkan hasil penyusunan dan analisis yang dilakukan yaitu terdapat beberapa hal terkait dengan identifikasi pola morfologi perkampungan adat Nagari Koto Hilalang Sumatera Barat berdasarkan kearifan lokal, meliputi:

1. Pola morfologi perkampungan adat Nagari Koto Hilalang berdasarkan kearifan lokal terlihat pada kearifan lokal masyarakatnya dalam mengatur segala tata kehidupan di perkampungan adat Nagari Koto Hilalang. Aturan dalam pembagian wilayah yang didasarkan kepada adat istiadat orang Minangkabau sehingga terbentuk taratak yang merupakan tingkatan terkecil dalam suatu wilayah. Dusun yang merupakan gabungan dari beberapa taratak yang telah berkembang, lalu koto yang merupakan gabungan dari beberapa dusun yang telah berkembang dan telah memiliki fasilitas-fasilitas. Serta nagari merupakan beberapa koto yang telah berkembang dan memiliki sistem pemerintahan.

2. Kearifan lokal yang membentuk pola morfologi dalam aturan adat istiadat dalam menentukan unsur sebuah nagari melalui ungkapan pepatah yaitu Balabuah (menghubungkan kampung dengan kampung), Batapian tampek mandi (tempat mandi umum), Babalai Adat (tempat pendidikan adat, musyawarah nagari, kaum ataupun suku dan tempat menegakkan hukum adat), Bamusajik (Ber-masjid tempat beribadah), Bagalanggang (tempat bermain bagi anak-anak muda).

3. Selain itu pola morfologi yang terbentuk juga dengan adanya pepatah Nan data kaparumah (Tanah yang datar untuk perumahan), Nan lereng tanami tebu (Tanah yang lereng untuk ditanami tebu), Nan payua karanang itiak (Tanah yang rawa untuk itik berenang), Nan barayia jadikan sawah (Tanah berair untuk persawahan), Nan munggu kapakuburan (Tanah yang tinggi untuk kuburan). Dari aturan yang dituangkan dalam pepatah tersebut dengan sendirinya membentuk suatu pola morfologi bagi nagari itu sendiri.

4. Berdasarkan kearifan lokal yang dimiliki oleh Nagari Koto Hilalang, maka perkampungan ini dapat digolongkan kepada bentuk Organik Pattern, dimana Nagari Koto Hilalang terbentuk secara natural/spontan, tidak terencana (hanya mengikuti aturan yang telah ditetapkan adat yang telah disepakati oleh orang-orang terdahulu). Alasan lain yaitu karena nagari ini berkembang sesuai dengan kebutuhan masyarakatnya serta juga dipengaruhi oleh kondisi topografi nagari yang berbukit dan berlembah, sedangkan untuk pola perkampungan, Nagari Koto Hilalang memiliki pola permukiman memusat, dimana pusatnya berada di kawasan Koto yang memiliki fasilitas-fasilitas berupa Balai Adat, Masjid, Sekolah, Lapangan yang dijadikan sebagai pusat aktivitas masyarkatnya.

Terkait dengan analisis yang telah dilakukan terdapat beberapa rekomendasi yang dapat dijadikan masukan bagi pihak-pihak yang terkait dengan perkampungan adat Nagari Koto Hilalang Sumatera Barat, yaitu:

1. Pemuka Adat

a. Diharapkan agar para pemuka adat yang meliputi niniak mamak, penghulu, cadiak pandai dan bundo kanduang sebagai orang yang paham dengan adat istiadat di Nagari Koto Hilalang dapat mengarahkan masyarakat untuk terus mempertahankan keaslian budaya yang ada agar tidak hilang seiring perkembangan zaman.

b. Tradisi-tradisi adat yang dahulunya cukup banyak dilakukan di Nagari Koto Hilalang sekarang sudah mulai hilang hanya beberapa saja yang masih rutin dilakukan. Agar 
tradisi yang merupakan warisan berharga yang dimiliki oleh Nagari Koto Hilalang tersebut tidak hilang maka diharapkan para pemuka adat agar dapat memberikan pelajaran mengenai kebudayaan agar tidak terlupakan.

2. Pemerintah

a. Diharapkan dapat membimbing masyarakatnya dalam mempertahankan keaslian adat yang ada di Nagari Koto Hilalang karena merupakan suatu warisan budaya yang memiliki nilai sejarah yang sangat penting.

b. Pemerintah Nagari Koto Hilalang perlu meningkatkan upaya pengembangan Perkampungan Adat Nagari Koto Hilalang sebagai kampung tradisi agar lebih dikenal oleh orang luar. Oleh sebab itu, perlu dilakukan promosi yang menarik agar dapat menarik minat orang untuk mendatangi kampung tersebut.

c. Diharapkan agar pemerintah dapat membimbing masyarakat di Nagari Koto Hilalang agar mempertahankan pola morfologi unik yang sudah dimiliki oleh nagari tersebut agar keaslian pola morfologi tetap terjaga.

d. Pemerintah diharapkan dapat memasukkan Nagari Koto Hilalang ke dalam kawasan yang dilindungi sebab memiliki kearifan lokal yang mencerminkan kebudayaan Minangkabau.

e. Disamping itu perlu dilakukan pemeliharaan terhadap bangunan-bangunan Rumah Gadang dan peninggalan-peninggalan sejarah yang ada di Nagari Koto Hilalang tersebut agar keutuhannya tetap terjaga.

3. Masyarakat Perkampungan Adat Nagari Koto Hilalang

a. Masyarakat setempat diharapkan dapat ikut serta dalam mempertahankan dan menjaga keaslian budaya yang ada di Nagari Koto Hilalang terutama para orang tua agar dapat membimbing anak-anak nya agar terus memahami dan mempertahankan keaslian budaya nagari yang mereka tinggali.

\section{Referensi}

Astuti, W. (2014). Model of Community-based Housing Development (CBHD) of Bedah Kampung Program in Surakarta Indonesia. Procedia Environmental Sciences, 20, 593-601. https://doi.org/10.1016/j.proenv.2014.03.072

Basyari, I. W. (2014). Nilai-Nilai Kearifan Lokal ( Local Wisdowm) Tradisi Memitu Pada Masyarakat Cirebon. Edunomic, 2(1), 47-56.

Dewi, G. (2010). Arsitektur Vernakular Minangkabau : Kajian Arsitektur dan Eksistensi Rumah Gadang Dilihat dari Pengaruh serta Perubahan Nilai Budaya. Universitas Indonesia.

Fatma, D. (2014). Kearifan Lokal Masyarakat Dalam Melestarikan Batang Aie Lunang Kecamatan Lunang Kabupaten Pesisir Selatan, 1-37. Retrieved from http://www.pesisirselatankab.go.id/

Heryanto, B. (2011). Roh dan Citra Kota. Surabaya: Brilian.

James, P., \& Bound, D. (2009). Urban morphology types and open space distribution in urban core areas. Urban Ecosystems, 12(4), 417-424. https://doi.org/10.1007/s11252-009-0083-1

Kostof, S. (1991). The City Shapes Urban Pattern and Meaning Through History. London: Library of Congress Cataloging in Publication Data.

Kusumawati, T. (2015). Penetapan Kawasan Adat Kampung Naga Sebagai Area Preservasi Atau Isolasi Dalam Upaya Menjaga Keberlanjutan Arsitektur Tradisional, (November), 1-11.

Nelisa, R. (2014). Identifikasi Bentuk Morfologi Perkampungan Berdasarkan Kearifan Lokal di Jorong Balimbiang Kenagarian Balimbiang Minangkabau. Universitas Diponegoro.

Qodariah, L. (2013). Nilai-Nilai Kearifan Lokal Masyarakat Adat Kampung Naga sebagai Alternatif Sumber Belajar. SOCIA: Jurnal Ilmu-Ilmu Sosial, 10(1), 10-20.

Soetomo, S. (2009). Urbanisasi dan Morfologi. Yogyakarta: Graha Ilmu.

Wahjoerini. (2014). Faktor-faktor yang Menentukan Eksistensi Kampung Pekojan sebagai Kampung Kota di Kota Semarang. Jurnal Pembangunan Wilayah Dan Kota, 10(1), 106-114.

Weishaguna, W. (2007). Morfologi Sebagai Pendekatan Memahami Kota. Jurnal Perencanaan Wilayah Dan Kota UNISBA, 7(2), 56-67. Retrieved from http://puslit2.petra.ac.id/ejournal/index.php/pwk/article/view/17763

Yunus, H. (1999). Struktur Tata Ruang Kota. Pustaka Pelajar.

Zahnd, M. (1999). Perancangan Kota Secara Terpadu. (H. Frick, Ed.). Yogyakarta: Kanisius dan Soegijapranata University Press. 